\title{
Physiological justification for obtaining high productivity of dairy cattle
}

\author{
Svetlana Khimicheva $^{1}$, Svetlana Moshkina $^{1}$, Anastasija Kharitonova $^{1}$, Natalija Abramkova $^{1}$
}

${ }^{1}$ Orel State Agrarian University named after N.V. Parakhin, 69, Generala Rodina str., Orel, 302019, Russia

\begin{abstract}
The article presents the results of studying the influence of the genealogical affiliation of animals and the origin of bulls, as well as the age of dairy cattle, on the quantitative and qualitative indicators of lactation performance. It is given the physiological justification for obtaining high productivity of dairy cattle. The results have shown that the use of bulls of different genotypes for insemination results in different productivity. So, according to the 305-day first and third lactation yields inseminated by the evaluated bulls, the bull-producer Baron 87485 of the Reflection Sovering line stands out. In terms of 305-day second lactation yield, the bull Adam 167 has the highest productivity. Analysis of the hematological picture makes it possible to establish that the blood parameters of the experimental animals, although they are within the physiologically acceptable norms, but the influence of bulls is noticeable on the content of erythrocytes, hemoglobin and total protein. This indicates and justifies more intensive processes with an increase in the lactation performance of dairy cattle.
\end{abstract}

\section{Introduction}

The main necessity in ensuring the nation health and food security of any country is an uninterrupted and sustainable public supply with quality food, including dairy products [1]. Dairy farming fulfills an important socio-economic and national-economic task, providing the population with valuable food products [2].

The increase in the production of high-quality milk and dairy products is one of the vital tasks in the development of animal husbandry all over the world, which becomes decisive both in connection with the global population growth, in particular in our country, and with the need to meet humanity needs for food $[3,4]$.

The milk productivity of cows is one of the most valuable breeding characteristics [5].

Recently, more and more attention has been paid to the breeding of dairy cows. The main task is the qualitative development and formation of highly productive herds here [6].

The main direction in breeding work with dairy cattle is still the use of the best specialized dairy breeds of the world gene pool [7].

The studies of biological changes in lactation performance, reproduction, as well as biological characteristics of animals are of particular importance for obtaining an objective judgment on the degree of realization of the genetic potential [8].

An increase in the milk efficiency of cows is inextricably linked with the intensification of selection work in dairy farming [4].

Breeding work in animal husbandry is aimed at improving the genetic and productive qualities of animals [9].
It is known that lactation performance can be increased due to the growth of the number of cattle and the productivity of dairy cows $[10,11]$. To increase lactation performance and improve the quality of milk, it is necessary a high-quality and constant development of animal husbandry. To achieve this goal, it is necessary to use a set of indices for assessing cattle [11, 12]. This assessment allows you to determine the most productive cows for further breeding and productive use. But it is impossible to choose dairy cattle without taking into account the factors affecting the quality and quantity of the product. According to some data, the level of milk productivity and the quality content of milk are lower for the following factors: some breeds of cattle, feeding and animal welfare, age, reproductive qualities, individual characteristics of cows, and their state of health. According to some authors, lactation performance can be different depending on the age of the cows. You can control the nature of age-related productivity [6].

Taking into account the above, the aim of the study is a comparative analysis of the productivity of dairy cows, as well as the physiological justification for obtaining high productivity of dairy cattle.

\section{Material and research methods}

The research has been carried out on black-and-white cattle. The study covers 52 cows. These cattle belong to the two main genealogical groups Reflection Sovering and Vis Back Ideal. We have used data from the breeding map for the analysis of lactation performance. Hematological analysis is carried out on automatic analyzers (hematological analyzer "Abacus junior vet", biochemical analyzer "Clima MC - 15") in the laboratory. 
The experimentally obtained material is processed using Microsoft Excel.

\section{Results and Discussion}

In accordance with the physiological laws of growth and development, a cow reaches physiological maturity at the age of 5-6 years (the age of the first fertilization is not earlier than 18 months and the third lactation) and continues to grow up to this age and, accordingly, the optimal conditions for feeding and keeping should respond to an increase in productivity, in our case, milk production per lactation [1].

The results of lactation performance in the analyzed population, depending on the genealogical affiliation and origin of bulls, as well as in the age aspect, are presented in Table 1, 2 and 3 and in Figure 1.

Table 1. First lactation yield

\begin{tabular}{|c|c|c|c|c|}
\hline \multirow{2}{*}{ trait } & \multicolumn{3}{|c|}{ Reflection Sovering } & Vis Back Ideal \\
\cline { 2 - 5 } & $\begin{array}{c}\text { Picasso 63463921 } \\
\text { I control group }\end{array}$ & $\begin{array}{c}\text { Baron 87485 } \\
\text { II group }\end{array}$ & $\begin{array}{c}\text { Adam 167 } \\
\text { III group }\end{array}$ & $\begin{array}{c}\text { Mart } 1207 \\
\text { IV group }\end{array}$ \\
\hline 305-day lactation yield,kg & $7821.54 \pm 411.18$ & $8035.92 \pm 432.07$ & $7749.85 \pm 452.51$ & $7198.00 \pm 302.84$ \\
\hline Fat,\% & $3.66 \pm 0.07$ & $3.64 \pm 0,10$ & $3.69 \pm 0.05$ & $3.84 \pm 0.04 * *$ \\
\hline Protein,\% & $3.19 \pm 0,01$ & $3.16 \pm 0,02^{*}$ & $3.21 \pm 0.02$ & $3.20 \pm 0.04$ \\
\hline
\end{tabular}

Note. * $-\mathrm{P}<0.05 ; * *-\mathrm{P}<0.01$.

Based on the data in Table 1, we note that according to 305-day first lactation yield inseminated by the evaluated bulls, the bull-producer Baron 87485 of the Reflection Sovering line stands out - the productivity of cows in this group is $214.38 \mathrm{~kg}$ higher than the control one; however, the animals of the control group outperform the dairy cattle of the third and fourth groups by $71.69 \mathrm{~kg}$ and $623.54 \mathrm{~kg}$, respectively. There is the highest fat content in milk in the first group, the bull March 1207 of the Vis Back Aydial line, which is 3.84\%, exceeding the control by $4.9 \%$. There is the lowest fat content in milk in the second group, the bull Baron 87485 Reflection Sovering line, which is $3.64 \%$, this indicator is less than the highest by $0.2 \%$ and the control group by $0.02 \%$. There is the highest protein content in milk in the third group, the bull Adam 167 of the Reflection Sovering line, which is $3.21 \%$, exceeding the control by $0.6 \%$. The lowest fat content in milk is observed in the second group, the bull Baron 87485 Reflection Sovering line, which is $3.16 \%$, this indicator is less than the highest by 0.05 and in the control group by $0.03 \%$.

Milk flow is an important indicator for assessing lactation performance, it characterizes the complex of anatomical and physiological properties that determine easy, fast, uniform and complete milking of the udder lobes.

The range of optimal milk flow rate is $1.5-2.5 \mathrm{~kg} / \mathrm{min}$. Analyzing the cows of the experimental groups according to the milk flow rate of first lactation dairy cattle, it can be seen that the bull Mart 1207 of the Vis Back Aydial line has the best milk flow rate of $2.27 \mathrm{~kg} / \mathrm{min}$, and the lowest one has the bull of the Picasso control group 63463921 of the Reflection Sovering line $-1.74 \mathrm{~kg} / \mathrm{min}$.

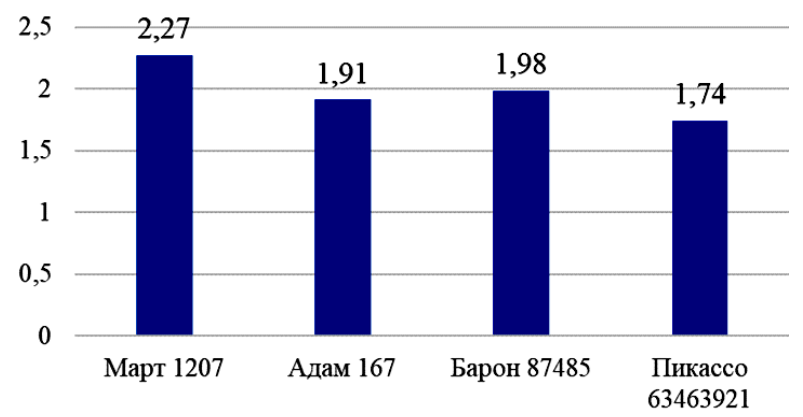

Fig. 1. Milk flow rate of the analyzed first lactation dairy cattle population

We should note that animals of all studied groups have values within the optimal range.

Table 2. Second lactation yield

\begin{tabular}{|c|c|c|c|c|}
\hline \multirow{2}{*}{ trait } & \multicolumn{3}{|c|}{ Reflection Sovering } & Vis Back Ideal \\
\cline { 2 - 5 } & $\begin{array}{c}\text { Picasso 63463921 } \\
\text { I group }\end{array}$ & $\begin{array}{c}\text { Baron 87485 } \\
\text { II group }\end{array}$ & $\begin{array}{c}\text { Adam 167 } \\
\text { III group }\end{array}$ & $\begin{array}{c}\text { Mart 1207 } \\
\text { IV group }\end{array}$ \\
\hline 305-day lactation yield,kg & $7156.00 \pm 409.00$ & $7332.46 \pm 525.63$ & $7699.00 \pm 305.84$ & $7374.39 \pm 210.56$ \\
\hline Fat,\% & $3.81 \pm 0.06$ & $3.80 \pm 0.11$ & $3.72 \pm 0.04$ & $3.67 \pm 0.07 *$ \\
\hline Protein,\% & $3.11 \pm 0.02$ & $3.07 \pm 0.01$ & $3.14 \pm 0.02$ & $3.21 \pm 0.04 * * *$ \\
\hline
\end{tabular}

Note. * ${ }^{*} \mathrm{P}<0.05 ; * * *-\mathrm{P}<0.001$

Analysis of table 2 has shown that in terms of 305-day second lactation yield, the bull Adam 167 has the highest productivity, and the bull of the Picasso control group 63463921 - the least. The bull of the control group has the highest fat content in milk, which is $3.81 \%$. The lowest fat content in milk is observed in the forth group, the bull Mart 1207 of the Vis Back Ideal line, which is $3.67 \%$, this indicator is less than the highest by $0.14 \%$.

The bull Mart 1207 of the Vis Back Ideal line has the highest protein content in milk, which is $3.21 \%$, exceeding the control by $0.1 \%$. The lowest fat content in 
milk is observed in the second group, the bull Baron 87485 Reflection Sovering line, which is equal to $3.07 \%$; this indicator is less than the highest by $0.14 \%$ and the control group by $0.04 \%$.

Table 3 Third lactation yield

\begin{tabular}{|l|l|l|l|l|}
\hline \multirow{2}{*}{ trait } & \multicolumn{2}{|l|}{ Reflection Sovering } & Vis Back Ideal \\
\cline { 2 - 5 } & $\begin{array}{l}\text { Picasso 63463921 } \\
\text { I group }\end{array}$ & $\begin{array}{l}\text { Baron 87485 } \\
\text { II group }\end{array}$ & $\begin{array}{l}\text { Picasso 63463921 } \\
\text { I group }\end{array}$ \\
\hline 305-day lactation yield,kg & $7658.46 \pm 447.46$ & $8523.00 \pm 380.82$ & $8030.62 \pm 380.52$ & $8356.92 \pm 396.14$ \\
\hline Fat,\% & $3.79 \pm 0.08$ & $3.79 \pm 0.09$ & $3.56 \pm 0.05^{* *}$ & $3.79 \pm 0.04$ \\
\hline Protein,\% & $3.13 \pm 0.02$ & $3.15 \pm 0.03$ & $3.12 \pm 0.02$ & $3.18 \pm 0.01^{*}$ \\
\hline
\end{tabular}

Note. * $-\mathrm{P}<0.05 ; * *-\mathrm{P}<0.01$.

From table 3 it can be seen that in terms of 305-day second lactation yield, the bull Baron 87485 has the highest productivity, and the bull of the control group has the least. The highest fat content in milk is observed in the second and third groups, which is 3.79\%. The bull Adam 167 of the Reflection Sovering line has the lowest fat content in milk, which is $3.56 \%$, this figure is $0.23 \%$ less than the highest. The bull March 1207 of the Vis Back Aydial line has the highest protein content in milk, which is $3.18 \%$, exceeding the control by $0.05 \%$. The lowest fat content in milk is observed in the third group, the bull Adam 167 of the Reflection Sovering line, which is $3.12 \%$, this indicator is less than the highest by $0.14 \%$ and the control group by $0.06 \%$.

Some insignificant biochemical changes in the blood occur within the physiological norm under the influence of various factors on the body, which reflect the desired and undesirable side of metabolism, and hence the possibility of assessing the tested factor.

During the research, it has been found that the use of bulls of different genotypes for insemination forms different productivity. We have studied the morphological and biochemical parameters of blood to determine the mechanism of the effect of productivity level on the organism of experimental dairy cattle.

Red blood cells and hemoglobin in the blood play a major role in the process of respiration and oxidation. Based on the studies, it has been noted that the content of erythrocytes is ranged from 6.69-6.91 $\times 10^{12} / 1$ in the blood of dairy cattle. The increase in this indicator is statistically significant in the second group, inseminated by the bull Baron 87485 . The difference with the control group is $0.17 \times 10^{12} / 1(\mathrm{p} \leq 0.05)$, or $2.5 \%$.

Hemoglobin plays an important role in respiration and the transport of oxygen throughout the body. It is a vital element of blood, the normal activity of all tissues and organs will depend on it. Cows of all experimental groups are characterized by a hemoglobin content not exceeding $119.2 \mathrm{~g} / 1$ at a rate of $99-129 \mathrm{~g} / 1$. It should be noted that animals of the second and forth groups, inseminated by the bull Baron 87485 of the Reflection Sovering line and Mart 1207 of the Vis Back Idial line, significantly exceed the animals of the control group in terms of this indicator. The difference with the control group is $5.4 \%$ and $4.9 \%$, respectively.

Higher productivity also affects the total protein content, which indicates a high level of interstitial metabolism, redox reactions and the state of the protective functions of the animal body. Thus, the content of total protein is significantly higher in the II group, inseminated by the bull Baron 87485 than that of the control group by $3.9 \mathrm{~g} / 1$ or $4.9 \%$.

The rest of the blood test parameters are in the same range, both in the control and in the experimental groups.

Thus, analyzing the hematological picture, it can be said that the blood parameters of the experimental animals, although they are within the physiologically permissible norms, have an effect on the content of erythrocytes, hemoglobin and total protein. This indicates more intensive processes with an increase in the milk productivity of dairy cattle.

\section{Conclusions}

During the research, it has been found that the use of bulls of different genotypes for insemination forms different productivity. So, according to 305-day first and third lactation yields, inseminated by the evaluated bulls, the bull-producer Baron 87485 of the Reflection Sovering line stands out. The bull Adam 167 has the highest productivity in terms of 305-day second lactation yield. Analyzing the data of experimental group cows of the first lactation according to the milk flow rate, it can be seen that the bull Mart 1207 bull of the Vis Back Ideal line has the best milk flow rate of $2.27 \mathrm{~kg} / \mathrm{min}$. The bull Baron 87485 of the Reflection Sovering line also has a high milk flow rate.

The bull Mart 1207 of the Vis Back Ideal line for the first and second lactation, and the bull Baron 87485 of the Reflection Sovering line for the third lactation are distinguished in terms of quality indicators of lactation performance.

Analysis of the hematological picture makes it possible to establish that the blood indices of the experimental animals, although they are within the physiologically permissible norms, the influence of bulls has been noticeable on the content of erythrocytes, hemoglobin and total protein. This indicates and justifies more intensive processes with an increase in the lactation performance of dairy cattle.

\section{References}

1. N.A. Fedoseeva et al IOP Conf. Ser.: Earth Environ. Sci. Evaluation of the efficiency of using blackmottled cows of the Ural type 677 (2021) 
2. A.R. Kuznetsova et al IOP Conf. Ser.: Earth Environ. Sci. The state and problems of increasing milk production in Russian Federation 315 (2019)

3. O.V. Gorelik et al IOP Conf. Ser.: Earth Environ. Sci. Comparative assessment of cows by daughters from different breeding bulls in terms of milk production $677(2021)$

4. O.V. Gorelik et al Conf. Ser.: Earth Environ. Sci. Influence of the age of cows on the dynamics of dairy efficiency depending on a breeding line IOP 677 (2021)

5. E.A. Alekseeva and E.V. Chetvertakova IOP Conf. Ser.: Earth Environ. Sci. Cow productivity index depending on their linearity 677 (2021)

6. L.V. Holodova et al IOP Conf. Ser.: Earth Environ. Sci. Comparative analysis of dairy cows' productivity depending on their origin and perspectives of further stock breeding in the herd 315 (2019)

7. E.S. Artemov et al IOP Conf. Ser.: Earth Environ. Sci. Economic use of cows of red-motley dairy breed in pedigree factories of Voronezh region 422 (2020)

8. S.D. Batanov et al IOP Conf. Ser.: Earth Environ. Sci. Genetic parameters of productivity and exterior traits of dairy cattle 548 (2020)

9. N. Shumeiko IOP Conf. Ser.: Earth Environ. Sci. Efficiency of breeding work in dairy cattle breeding 274 (2019)

10. S. V. Moshkina, S. N Khimicheva. In the coll.: A coll. of sci. papers of the Tenth All-Rus. Interuniv. Conf. on Clinic. Vet. Med. in the format of Purina Partners Correction of the immunological status of calves as the basis for high productivity and healthy livestock of the herd 330 (Moscow, 2020)

11. S. N. Khimicheva, S. V. Moshkina In the coll.: Inn. in sci. and tech. sup. of the agro-ind. complex of Rus. materials of the All-Russ. (Nat.) Scie. and Pract. Conf Milk productivity of black-and-white cows depending on the influence of various factors 158 (Kursk, 2020)

12. A. S. Kharitonova, S. V. Moshkina In the coll.: Ach. and prosp. for the imp. of nat. proj. for the develop. of the agro-ind. complex. Coll. of sci. papers on the res. of the VIII Int. Sci. and Pract. Conf. dedic. to the memory of the Hon. Sci. of the Rus. Fed. and the KBR, Prof. B. Kh. Zherukov Tribal resources of the Orel region 267 (2020) 